\title{
INDUCTION OF MUTATION BY GAMMA IRRADIATION AND EMS IN CAJANUS CAJAN. L.
}

\author{
Mundeep G. Awaley \\ Department of Botany, Bhawabhuti Mahavidyalaya, Amgaon, M.S., India. \\ mundeepawaley@,rediffmail.com
}

\begin{abstract}
:
The plants of Cajanus cajan were grown in plots from seeds obtained from Krishi Vigyan Kendra, Gondia. The well developed seeds of same age will be selected and will be subjected to gamma irradiation doses. Prior to the mutagenic treatments, all genotypes were grown for one generation to ensure their homozygosity. The well developed seeds of same age were selected and subjected to gamma irradiation doses of 100, 200, 300, 400, 500, $600,700,800,900,1000,1100$ and 1200 Gy (Gray) (40 seeds for each treatment in four genotypes). Gamma irradiation will be carried out at at room temperature $\left(22-25^{\circ} \mathrm{C}\right)$ in a Cobalt 60 gamma cell-220 of 381.43 curie strength delivering $29 \mathrm{kR} / \mathrm{hr}$ at the time of irradiation. For EMS treatment, the seeds were presoaked in sterile distilled water for 6 hours and then treated with different concentrations of EMS (10, 20, 30 and 40mM) for 8 hours. The mutagen treated and control (untreated) seeds were sown in the field in randomized block design (RDB), with three replications. The seeds of all individual M, plants were harvested separately and they were sown in the field during the next Kharif to rise $\mathrm{M}_{1}$ generation.
\end{abstract}

Key words: - Cajanus cajan, Gamma irradiation, EMS.

\section{INTRODUCTION:}

\section{Introduction}

Cajanus cajan L. (Millsp), commonly known as Pigeonpea or Red gram, is an important legume crop widely used as food and fodder and is a major source of vegetable protein. Pigeonpea is an economic source of not only protein but of carbohydrate, minerals and Bcomplex vitamins particularly in vegetarian diet (Salunkhe et al., 1985). Pigeonpea, being a self-pollinated crop, the available genetic variability has been almost exploited for improvement by conventional breeding methods. Therefore it becomes necessary to creat genetic variability through induced mutations. Induced mutagenesis has been used very widely in crop plants to creat genetic variability in traits of economic value. Chlorophyll mutations are one of the important criteria to determine effectiveness of the mutagens. According to Mille(1968), in spite of impaired seed production, the chlorophyll mutants are potentially useful in understanding of different physiological functions, various biochemical reactions and pathological invasion. Although mutagens bring about changes in nucleotide sequence of DNA, the mode of action of each mutagen is distinct. More ever, a mutagen may effectively bring about mutations, but the accompanying undesirable effects like lethality or sterility may decrease its efficiency. Thus in order to exploit induced mutagenesis for crop improvement, the basic studied on effectiveness and efficiency of a mutagen in a crop are necessary (Badere and Chaudhary, 2007). The literature reveals that the mutational work on pigeonpea has been scanty. In the present investigation, efforts were made to assess the effect of different concentrations of EMS and different doses of gamma irradiation on Pigeonpea to find out 
effective concentration, which induces desirable mutations.

In the last decade, gamma irradiation has been drawn the attention as a new and rapid method to improve the qualitative and quantitative characters of many crops. Previous studies have shown relatively low doses ionising radiation on plants and microorganisms are manifested as accelerated cell proliferation, germination rate, cell growth, enzyme activity, stress resistance and crop yields (Chakravarthy and Sen, 2001). Inhibition of seed germination, shoot and root elongation have been reported for detection of irradiated cereal grains and legumes. Chaudhuri (2002) reported that the irradiation of wheat seeds reduced shoot and root lengths upon germination. Gamma radiation can be useful for the alteration of physiological characters (Kiong et al 2008). The biological effect of gamma rays is based on the interaction with atoms or molecules in the cell, particularly water, to produce free radicals (Kova'cs and Keresztes 2002.)

\section{MATERIAL \& METHODS:}

\section{Variety used}

Pure line seeds of local variety of Cajanus cajan L. were used in the present study. The certified, healthy and dry seeds (10\% moisture content) of this variety were procured from Krishi Vigyan Kendra, Gondia. This variety well adapted to the agro climatic conditions.

\section{Mutagens used}

The seeds of pigeonpea were treated with different doses / treatments of physical and chemical mutagens. The physical mutagen used was gamma rays and chemical mutagens included Ethyl Methane Sulphonate (EMS )

\section{Gamma rays}

Prior to the mutagenic treatments, all genotypes, were grown for one generation to ensure their homozygosity. Uniform healthy dry seeds $(10 \%$ moisture content) of the Pigeonpea were exposed to different doses of gamma rays (100Gy, 200Gy, 300Gy, 400Gy, 500Gy, 600Gy, 700Gy, 800Gy, 900Gy, $1000 \mathrm{~Gy}, 1100 \mathrm{~Gy}$ and $1200 \mathrm{~Gy}$ ) with a dose rate of $14.5 \mathrm{Kr} / \mathrm{hr}$. from 60 Cobalt source at the Department of Chemistry, Rashtrasant Tukadoji Maharaj Nagpur University, Nagpur.

\section{Ethyl methane sulphonate [EMS (CH3 OSO2} C2H5)]

Germplasm of the experimental plant material, pigeonpea were procured from Krishi Vigyan Kendra, Gondia (Maharashtra state). The seeds were presoaked in sterile distilled water for 6 hours and then treated with different concentration of EMS $(10,20,30$, and $40 \mathrm{mM}$ for 8 hours. The mutagen treated and control (Untreated) seeds were sown in field in randomized block design (RDB), with three replications. The seeds of all indivisual $M$ plants were harvested separately and they were sown in the field during the next Kharif to rise $M_{1}$ generation. Mutagenic effect was assessed using parameters like seed germination, plant survival, pollen sterility, pod length, grain yield, branching pattern and chlorophyll mutants. The treated as well as control seeds after germination were carefully screened for mutation in $\mathrm{M}_{1}$ generation.

\section{Method of treatment with chemical mutagen}

Prior to the mutagenic treatment, the seeds were presoaked in distilled water for a period of $12 \mathrm{hr}$. Seed presoaking allows the cells to reach a metabolic state when they are relatively more sensitive to mutagenic action. The control seeds were also immersed in distilled water for the same duration. Thus the control seeds although not treated with the chemical mutagens, were exposed to similar physiological conditions before sowing as that of treated seeds. The seeds were given 
intermittent shaking throughout the treatment period (6hr) to provide sufficient aeration. For uniform absorption, large quantities of mutagenic solution, approximately three times the volume of seeds (Konzak et al., 1965) were used. After the completion of treatment period, the seeds were thoroughly washed in running tap water for 20min to remove the excess chemicals from the seed surface before they were sown in the field.

\section{Sample size}

A set of 150 seeds were chosen for each dose/treatment including the control. Out of these 150 seeds, 100 seeds for each treatment and control were sown in the field for morphological and cytological studies, whereas the remaining set of 50 seeds was allowed to germinate on moist cotton in Petriplates for measuring root-shoot length.

\section{Sowing of seeds in the field}

Nursery beds were prepared for sowing seeds and raising $M_{1}$ generation. In January, 2014, the treated as well as untreated (control) seeds were sown in three replicates in a Complete Randomized Block Design (CRBD) at the Bhawabhuti Mahavidyalaya, Amgaon. The distance between the seeds along a row was kept $5 \mathrm{~cm}$ whereas row to row distance was maintained at $10 \mathrm{~cm}$ in each experimental plot in a replication. Table 1: Details of Mutagenic Treatment
given to Pigeonpea seeds

\begin{tabular}{|l|l|l|l|}
\hline $\begin{array}{l}\text { Mutage } \\
\text { nused }\end{array}$ & $\begin{array}{l}\text { Dose/ } \\
\text { Concentrati } \\
\text { on }\end{array}$ & $\begin{array}{l}\text { Duration } \\
\text { of } \\
\text { Presoakin } \\
\text { g (Hrs.) }\end{array}$ & $\begin{array}{l}\text { Duration } \\
\text { of } \\
\text { Treatme } \\
\text { nt (Hrs.) }\end{array}$ \\
\hline Control & DDW & 6.0 & - \\
\hline Gamma & 100 & - & - \\
rays & 200 & - & - \\
(GY) & 300 & - & - \\
& 400 & - & - \\
& 500 & - & - \\
& 600 & - & - \\
& 700 & - & - \\
& 800 & - & - \\
& 900 & - & - \\
& 1000 & - & - \\
& 1100 & - & - \\
\hline EMS & 1200 & - & - \\
(\%) & 0.1 & 6.0 & 8.0 \\
& 0.2 & 6.0 & 8.0 \\
& 0.3 & 6.0 & 8.0 \\
\hline
\end{tabular}

\section{Mechanism of action of physical and chemical mutagens}

\section{a) Physical mutagens}

Gamma rays are the most energetic form of electromagnetic radiation, possessing the energy level from 10 kilo electron volts (kev) to several hundred kev, and they are considered the most penetrating in comparison to other radiation such as alpha and beta rays (Kovacs and Keresztes, 2002). The common sources of gamma rays are 137 Cs (half-life 30 years, energy $0.66 \mathrm{Mev}$ ) and 60 Co (half-life 53 years, energies 1.33 Mev, 1.17 Mev). Gamma rays belong to ionizing radiation and interact with atoms or molecules to produce free radicals in cells. These radicals can damage or modify important components of plant cells and have been reported to affect differentially the morphology, anatomy, biochemistry and physiology of plants depending on the irradiation level. These effects include changes in the plant cellular structure and metabolism e.g., dilation of thylakoid membranes, 
alteration in photosynthesis, modification of the anti-oxidative system and accumulation of phenolic compounds (Kim et al., 2004, Wi et al., 2005). The biological effects produced by a radiation depend upon the total amount of radiation energy absorbed or delivered in an organism. The dose of radiation is measured as the amount of energy absorbed per unit mass of the irradiated object and is commonly expressed as rad. One rad equals $100 \mathrm{erg} / \mathrm{g}$ or $10-2 \mathrm{j} / \mathrm{kg}$ of irradiated object. The unit of radiation dose is called Gray (Gy). Gy equals $100 \mathrm{rad}$ or $1 \mathrm{~J} / \mathrm{kg}$ of the irradiated object.

\section{b) Chemical mutagen}

Ethyl methane sulphonate, a mono functional alkylating agent is a colourless liquid soluble in water with a boiling point $85.86 \mathrm{o} \mathrm{C} / 10 \mathrm{~mm} \mathrm{Hg}$. In the action of EMS on biological systems, triester is the main target. It has been established by many workers that primary reaction centres in the DNA are the alkylation of its phosphate groups. The resulting triester is unstable and tends to lose the alkyl group. The unstable phosphate triester can hydrolyse between the phosphate and deoxyribose resulting in the backbone breakage. EMS is known to induce alkylation of purine and pyrimidine bases. Alkylation is thought to occur most readily with guanine at position N7 followed by Adenine at N3 and rarely with $\mathrm{N}$ in cytosine. However, no reaction with thymine has been detected. Alkylation of the nitrogenous ring ultimately leads to the removal of the alkylated base i.e., depurination or depyrimidation and may lead to back bone breaks. EMS is also known to induce transitions e.g., alkylation of guanine results in the formation of o 6 -ethyl guanine, which can pair with thymine (T) but not with cytosine (C). Through subsequent DNA repair, the original G/C pair can then be replaced with
A/T (Greene et al., 2003). In majority of cases (99\%), EMS induces C-to-T changes resulting in $\mathrm{C} / \mathrm{G}$ to $\mathrm{T} / \mathrm{A}$ substitutions (Kreig, 1963). The mutagenicity is mediated through the production of an organic metabolite of azide compound (Owais and Klienhofs, 1988).This metabolite enters into the nucleus, interacts with DNA and creates point mutations in the genome. These effects, caused by NaN3, together may hamper ATP biosynthesis resulting in decreased availability of ATP molecule which may slow the germination rate and reduce the germination percentage.

\section{Evaluation of M1 generation Seed germination}

The data on seed germination was recorded right from the emergence of first shoot in each treatment including control. After recording the data, percentage of seed germination was calculated by using the formula

Germination $(\%)=\underline{\text { No.of seeds germinated }} \times 100$ No.of seeds sown

\section{Seedling height $(\mathrm{cm})$}

Seedling height was estimated on 9 th day of germination by measuring root and shoot lengths of 15 randomly selected seedlings from each treatment as well as control. Seedling injury, as measured by the reduction in root and shoot length and calculated in terms of percentage of root and shoot injury.

Percent injury $=\frac{\text { Control-Treated }}{\text { Control }} \times 100$

\section{Plant survival}

The surviving plants in different treatments were counted at the time of maturity and the survival percentage and percent lethality were calculated by the following formula.

Survival $(\%)=\quad$ Number of plants at maturity $\times 100$ Number of seeds germinated 
Lethality $(\%)=\underline{\text { Control-Treated }} \times 100$

Control

\section{Quantitative characters of M1 generation}

The following morphological parameters were recorded in M1 generation

i) Plant height (cm): The height of 15 randomly selected plants was measured from the point above the ground to the tip of the main axis of the plant.

ii) Number of pods per plant: Total number of pods per plant for a selected number of 15 plants from each concentration including control was recorded.

iii) Length of pods per plant (cm): The length of five pods per plant from 15 randomly selected plants in each treatment including control was recorded.

iv) Number of seeds per pod: Five pods per plant from 15 randomly selected plants in each treatment were used to calculate the mean seeds per pod.

v) Seed yield per plant (g): Randomly selected 15 plants per treatment were used for calculating the mean seed yield per plant.

Effect of Gamma irradiation and EMS treatment on Seed Germination and Plant Survival.

The mutagenic effects of gamma rays, EMS were studied on seed germination, seedling height, plant survival and various quantitative characters in M1 generation of pigeonpea.

\section{Seed germination}

Germination percentage was found to be significantly reduced in all the mutagenic treatments. The maximum inhibition in germination was recorded at higher treatments of all mutagens. Seed germination was about $96 \%$ in control. In gamma rays it ranged from $84 \%$ (100Gy) to 9\% (900Gy). In case of EMS treatments it ranged from $68 \%(10 \mathrm{mM})$ to $48 \%$
$(40 \mathrm{mM})$. The pooled mean values showed that gamma rays were most effective in reducing the seed germination followed by EMS.

\section{Plant survival}

Plant survival was higher in control $(95.20 \%)$ than in all the three mutagenic treatments (Table 2). Plant survival tended to decrease with the increase in the dose / concentration of mutagens. In case of gamma rays highest lethality was observed at 900Gy (9\%). In EMS treatments maximum lethality was noticed at $40 \mathrm{mM}$ concentration (48\%).

\section{Seedling height}

Data recorded on seedling height measured in terms of root+shoot length is presented in table 4. It is evident from that seedling height decreased with an increase in dose / concentration of mutagens. Control populations exhibited the highest seedling height of $17.82 \mathrm{~cm}$. Among the mutagenic treatments maximum injury was recorded in 900Gy treatment (9\%). The pooled mean values for seedling height and percent injury indicated that gamma rays were more effective followed by EMS treatments.

Table 2: Effect of gamma rays on Percent Seed germination, Pollen sterility and plant survival in M1 generation in Cajanus cajan L.

\begin{tabular}{|l|l|l|l|l|}
\hline $\begin{array}{l}\text { Treatm } \\
\text { ents }\end{array}$ & $\begin{array}{l}\text { Germina } \\
\text { tion (\%) }\end{array}$ & $\begin{array}{l}\text { Plant } \\
\text { Survi } \\
\text { val } \\
(\%)\end{array}$ & $\begin{array}{l}\text { Letha } \\
\text { lity } \\
(\mathrm{L})\end{array}$ & $\begin{array}{l}\text { Pollen } \\
\text { sterili } \\
\text { ty\% }\end{array}$ \\
\hline Control & 96.00 & 95.20 & - & 0.00 \\
\hline $\begin{array}{l}\text { Gamma } \\
\text { rays }\end{array}$ & & & & \\
\hline 100 Gy & 84.00 & 90.14 & 9.86 & 4.59 \\
\hline 200 Gy & 76.00 & 88.40 & 11.6 & 7.11 \\
\hline 300 Gy & 68.00 & 86.18 & 13.82 & 9.00 \\
\hline 400 Gy & 49.00 & 76.52 & 23.48 & 30.68 \\
\hline 500Gy & 38.00 & 66.23 & 33.77 & 39.00 \\
\hline 600 Gy & 31.00 & 52.12 & 47.88 & 46.00 \\
\hline 700 Gy & 26.00 & 40.21 & 59.79 & 62.16 \\
\hline 800 Gy & 17.00 & 29.54 & 70.46 & 69.11 \\
\hline 900 Gy & 9.00 & 18.68 & 81.32 & 78.55 \\
\hline Mean & 44.22 & 60.89 & 39.10 & 38.46 \\
\hline
\end{tabular}


Table 3: Effect of EMS on Percent Seed germination, Pollen sterility and plant survival in M1 generation in Cajanus cajan L.

\begin{tabular}{|l|l|l|l|l|}
\hline $\begin{array}{l}\text { Treatm } \\
\text { ents }\end{array}$ & $\begin{array}{l}\text { Germinat } \\
\text { ion(\%) }\end{array}$ & $\begin{array}{l}\text { Plant } \\
\text { Surviv } \\
\text { al(\%) }\end{array}$ & $\begin{array}{l}\text { Letha } \\
\text { lity } \\
(\mathrm{L})\end{array}$ & $\begin{array}{l}\text { Pollen } \\
\text { sterili } \\
\text { ty\% }\end{array}$ \\
\hline Control & 96.00 & 95.20 & - & \\
\hline EMS & & & & \\
\hline $10 \mathrm{mM}$ & 68.00 & 86.66 & 13.34 & 5.28 \\
\hline $20 \mathrm{mM}$ & 60.00 & 75 & 25 & 10.21 \\
\hline $30 \mathrm{mM}$ & 57.00 & 71.43 & 28.57 & 9.22 \\
\hline $40 \mathrm{mM}$ & 48.00 & 60 & 40 & 16.66 \\
\hline Mean & 58.25 & 73.27 & 21.72 & 10.34 \\
\hline
\end{tabular}

Table 4: Effect of Gamma Radiation on Shoot Length, Root Length and Number of Lateral Roots of Cajanus cajan (L) Millsp. Seedlings

\begin{tabular}{|l|l|l|l|l|}
\hline $\begin{array}{l}\text { Radiation } \\
\text { Doses }\end{array}$ & $\begin{array}{l}\text { Shoot } \\
\text { Length }\end{array}$ & $\begin{array}{l}\text { Root } \\
\text { Length }\end{array}$ & $\begin{array}{l}\text { Total } \\
\text { Seedling } \\
\text { Length }\end{array}$ & $\begin{array}{l}\text { No. of } \\
\text { Lateral } \\
\text { Roots }\end{array}$ \\
\hline Control & 7.69 & 10.13 & 17.82 & 14.12 \\
\hline 100 Gy & 7.67 & 10.10 & 17.77 & 13.23 \\
\hline 200 Gy & 7.66 & 9.92 & 17.58 & 9.43 \\
\hline 300 Gy & 7.60 & 9.33 & 16.93 & 8.96 \\
\hline 400 Gy & 7.52 & 8.14 & 15.66 & 8.44 \\
\hline 500 Gy & 7.44 & 6.92 & 14.36 & 7.23 \\
\hline 600 Gy & 5.56 & 3.51 & 9.07 & 7.13 \\
\hline 700 Gy & 5.12 & 2.22 & 7.34 & 6.56 \\
\hline 800 Gy & 4.32 & 2.12 & 6.44 & 4.22 \\
\hline 900 Gy & 4.11 & 2.00 & 6.11 & 3.36 \\
\hline
\end{tabular}

Table 5: Effect of EMS on Shoot Length, Root Length and Number of Lateral Roots of Cajanus cajan (L) Millsp. Seedlings

\begin{tabular}{|l|l|l|l|l|}
\hline $\begin{array}{l}\text { EMS } \\
\text { Doses }\end{array}$ & $\begin{array}{l}\text { Shoot } \\
\text { Length }\end{array}$ & $\begin{array}{l}\text { Root } \\
\text { Length }\end{array}$ & $\begin{array}{l}\text { Total } \\
\text { Seedling } \\
\text { Length }\end{array}$ & $\begin{array}{l}\text { No. of } \\
\text { Lateral } \\
\text { Roots }\end{array}$ \\
\hline Control & 7.69 & 13.13 & 20.82 & 14.12 \\
\hline $10 \mathrm{mM}$ & 6.22 & 11.13 & 17.35 & 12.12 \\
\hline $20 \mathrm{mM}$ & 6.12 & 7.92 & 14.04 & 9.21 \\
\hline $30 \mathrm{mM}$ & 5.59 & 7.33 & 12.92 & 8.56 \\
\hline $40 \mathrm{mM}$ & 5.23 & 6.14 & 11.37 & 8.41 \\
\hline
\end{tabular}

\section{Studies on quantitative characters}

\section{i) Plant height (cm)}

A progressive decrease in plant height was observed with an increase in concentration of Gamma irradiation. The plant height at 100Gy, 200Gy, 300Gy, 400Gy, 500Gy, 600Gy, 700Gy, 800Gy and 900Gy was $106.6 \mathrm{~cm}, 106.1$ $\mathrm{cm}, 106.00 \mathrm{~cm}, 101.8 \mathrm{~cm}, 100.6 \mathrm{~cm}, 100.2$ $\mathrm{cm}, 98.0 \mathrm{~cm}, 96.2 \mathrm{~cm}, 96.00 \mathrm{~cm}$ and $94.21 \mathrm{~cm}$ respectively as against $106.7 \mathrm{~cm}$ in control. The plant height at $10 \mathrm{mM}, 20 \mathrm{mM}, 30 \mathrm{mM}$ and $40 \mathrm{mM}$ of EMS was $106.00 \mathrm{~cm}, 108.00 \mathrm{~cm}$, $106.00 \mathrm{~cm}$ and $105.00 \mathrm{~cm}$ respectively. The plant height is found maximum in $20 \mathrm{mM}$ concentration of EMS. i.e $108 \mathrm{~cm}$. (Table 5 and $6)$.

\section{ii) Number of pods/plant}

A progressive decrease in No. of pods per plant was observed with an increase in concentration of Gamma irradiation. The No. of pods per plant at 100Gy, 200Gy, 300Gy, 400Gy, 500Gy, 600Gy, 700Gy, 800Gy and 900Gy were $185,180,177,175,170,151$, 150, 150, and 150 respectively as against 187 in control. The No. of pods per plant at $10 \mathrm{mM}$, $20 \mathrm{mM}, 30 \mathrm{mM}$ and $40 \mathrm{mM}$ of EMS were 184 , 187, 180 and 178 respectively. No. of pods per plant are found equals to control at $20 \mathrm{mM}$ concentration of EMS. i.e. 187. (Table 5 and 6).

\section{iii) Pod length (cm)}

The Pod length of different concentration of Gamma irradiation at 100Gy, 200Gy, 300Gy, 400Gy, 500Gy, 600Gy, 700Gy, 800Gy and 900Gy was $5.6 \mathrm{~cm}, 5.6 \mathrm{~cm}, 5.6 \mathrm{~cm}, 5.5 \mathrm{~cm}$, $5.5 \mathrm{~cm}, 5.5 \mathrm{~cm}, 5.5 \mathrm{~cm}, 5.4 \mathrm{~cm}, 5.3 \mathrm{~cm}$ and $5.3 \mathrm{~cm}$ respectively as against $5.6 \mathrm{~cm}$ in control. The maximum pod length was found at 100Gy and 200Gy i.e $5.6 \mathrm{~cm}$ as in control. The Pod length at $10 \mathrm{mM}, 20 \mathrm{mM}, 30 \mathrm{mM}$ and $40 \mathrm{mM}$ of EMS treatment was $5.6 \mathrm{~cm}, 5.6 \mathrm{~cm}$, $5.50 \mathrm{~cm}$ and $5.5 \mathrm{~cm}$ respectively. The Pod 
length is found maximum in $20 \mathrm{mM}$ and 20 $\mathrm{mM}$ concentration of EMS. i.e $5.6 \mathrm{~cm}$. as in control. (Table 5 and 6).

\section{iv) Number of seeds per pod}

The No. of seeds per pod of different concentration of Gamma irradiation at 100Gy, 200Gy, 300Gy, 400Gy, 500Gy, 600Gy, 700Gy, 800Gy and 900Gy was 6, 6, 5, 6, 5, 6, 6, 5, 6 and 5 respectively as against 6 in control. The pod length is found 6 at 100Gy, 200Gy, 400Gy, 600Gy, 700Gy and 800Gy i.e 6 no. as in control. The No. of seeds per pod of EMS treatment was 6 No. in all the concentration of EMS. (Table 5 and 6).

\section{v) Seed yield per plant (g)}

The Seed yield per plant at 100Gy, 200Gy, 300Gy, 400Gy, 500Gy, 600Gy, 700Gy, 800Gy and 900Gy were $150.96 \mathrm{gm}, 146.88 \mathrm{gm}$, $144.43 \mathrm{gm}, 119.00 \mathrm{gm}, 138.72 \mathrm{gm}, 123.21$ gm, $102.00 \mathrm{gm}, 122.4 \mathrm{gm}$, and $102.00 \mathrm{gm}$ respectively as against $152.89 \mathrm{gm}$ in control. The seed yield per plant at $10 \mathrm{mM}, 20 \mathrm{mM}$, $30 \mathrm{mM}$ and $40 \mathrm{mM}$ of EMS treatment were $150.90 \mathrm{gm}, 152.80 \mathrm{gm}, 146.50 \mathrm{gm}$ and $120 \mathrm{gm}$ respectively. (Table 5 and 6 ).

Table 5: Effect of Different doses of gamma irradiation on Plant height, No. of pods per planty, Pod length, No. of seeds per pod and seed yield per plant.

\begin{tabular}{|c|c|c|c|c|c|}
\hline $\begin{array}{l}\text { Doses/ } \\
\text { Concentra } \\
\text { tion }\end{array}$ & $\begin{array}{l}\text { Plan } \\
\text { t } \\
\text { Heig } \\
\text { ht } \\
\text { (cm) }\end{array}$ & $\begin{array}{l}\text { No. } \\
\text { of } \\
\text { pods } \\
\text { per } \\
\text { plan } \\
\text { t } \\
\end{array}$ & $\begin{array}{l}\text { Pod } \\
\text { length( } \\
\mathrm{cm})\end{array}$ & $\begin{array}{l}\text { No. } \\
\text { of } \\
\text { see } \\
\text { ds } \\
\text { per } \\
\text { pod }\end{array}$ & $\begin{array}{l}\text { Seed } \\
\text { yiel } \\
\text { d } \\
\text { per } \\
\text { plan } \\
\text { t (g) }\end{array}$ \\
\hline Control & $\begin{array}{l}106 . \\
7\end{array}$ & 187 & 5.6 & 6 & $\begin{array}{l}152 . \\
89\end{array}$ \\
\hline 100 Gy & $\begin{array}{l}106 . \\
6\end{array}$ & 185 & 5.6 & 6 & $\begin{array}{l}150 . \\
96\end{array}$ \\
\hline $200 \mathrm{~Gy}$ & $\begin{array}{l}106 . \\
1\end{array}$ & 180 & 5.6 & 5 & $\begin{array}{l}146 . \\
88\end{array}$ \\
\hline 300 Gy & $\begin{array}{l}106 . \\
00\end{array}$ & 177 & 5.5 & 6 & $\begin{array}{l}144 . \\
43\end{array}$ \\
\hline $400 \mathrm{~Gy}$ & $\begin{array}{l}101 \\
8\end{array}$ & 175 & 5.5 & 5 & $\begin{array}{l}119 . \\
00\end{array}$ \\
\hline $500 G y$ & $\begin{array}{l}100 . \\
6\end{array}$ & 170 & 5.5 & 6 & $\begin{array}{l}138 . \\
72\end{array}$ \\
\hline $600 \mathrm{~Gy}$ & $\begin{array}{l}100 . \\
2\end{array}$ & 151 & 5.5 & 6 & $\begin{array}{l}123 \\
21\end{array}$ \\
\hline 700 Gy & $\begin{array}{l}98.0 \\
0 \\
\end{array}$ & 150 & 5.4 & 5 & $\begin{array}{l}102 . \\
00\end{array}$ \\
\hline
\end{tabular}

\begin{tabular}{|l|l|l|l|l|l|}
\hline $\mathbf{8 0 0}$ Gy & 96.2 & 150 & 5.3 & 6 & $\begin{array}{l}122 . \\
4\end{array}$ \\
\hline 900 Gy & $\begin{array}{l}96.0 \\
0\end{array}$ & 150 & 5.3 & 5 & $\begin{array}{l}102 . \\
00\end{array}$ \\
\hline Mean & $\begin{array}{l}94.2 \\
1\end{array}$ & $\begin{array}{l}140 . \\
46\end{array}$ & 5.28 & $\begin{array}{l}5.3 \\
3\end{array}$ & $\begin{array}{l}99.3 \\
7\end{array}$ \\
\hline
\end{tabular}

Table 6: Effect of Different EMS on Plant height, No. of pods per plant, Pod length, No. of seeds per pod and seed yield per plant.

\begin{tabular}{|c|c|c|c|c|c|}
\hline $\begin{array}{l}\text { Doses/ } \\
\text { Concent } \\
\text { ration }\end{array}$ & $\begin{array}{l}\text { Plant } \\
\text { Height } \\
\text { (cm) }\end{array}$ & $\begin{array}{l}\text { No. } \\
\text { of } \\
\text { po } \\
\text { ds } \\
\text { per } \\
\text { pla } \\
\text { nt }\end{array}$ & $\begin{array}{l}\text { Pod } \\
\text { length } \\
(\mathrm{cm})\end{array}$ & $\begin{array}{l}\text { No. } \\
\text { of } \\
\text { see } \\
\text { ds } \\
\text { per } \\
\text { po } \\
\text { d }\end{array}$ & $\begin{array}{l}\text { See } \\
\text { d } \\
\text { yiel } \\
\text { d } \\
\text { per } \\
\text { pla } \\
\text { nt } \\
\text { (g) }\end{array}$ \\
\hline Control & 106.75 & $\begin{array}{l}18 \\
7\end{array}$ & 5.6 & 6 & $\begin{array}{l}152 \\
.89\end{array}$ \\
\hline $10 \mathrm{mM}$ & 106.00 & $\begin{array}{l}18 \\
4\end{array}$ & 5.6 & 6 & $\begin{array}{l}150 \\
.90\end{array}$ \\
\hline $20 \mathrm{mM}$ & 108.00 & $\begin{array}{l}18 \\
7\end{array}$ & 5.6 & 6 & $\begin{array}{l}152 \\
.80\end{array}$ \\
\hline $30 \mathrm{mM}$ & 106.00 & $\begin{array}{l}18 \\
0\end{array}$ & 5.5 & 6 & $\begin{array}{l}146 \\
.50\end{array}$ \\
\hline $400 \mathrm{mM}$ & 105.00 & $\begin{array}{l}17 \\
8\end{array}$ & 5.5 & 6 & $\begin{array}{l}120 \\
.00\end{array}$ \\
\hline Mean & 105.3 & $\begin{array}{l}17 \\
6.6\end{array}$ & 5.47 & 6 & $\begin{array}{l}123 \\
.56\end{array}$ \\
\hline
\end{tabular}

\section{RESULT \& DISCUSSION:}

Percent seed germination decreased with an increase in concentration/dose of mutagen in both cultivars in M1 generation (Table-2). The decrease in germination was more conspicuous with gamma radiation treatment than that of EMS. The germination for control was $96 \%$. The seed germination decreased from $96 \%$ to $9 \%$ by treatment of gamma irradiation. The maximum decrease in seed germination was observed in with 900Gy Gamma irradiation and 40mM EMS treatment. The result also shows that 100Gy dose of gamma was less toxic to seed germination. The sensitivity of pigeon pea may be due to metabolic processes affected at embryonic level reported by Ashri and Herzog (1972).Similar inhibitory effects on seed germination observed 
by Mundhe \& Borse (2012), and Khan \& Wani (2006).

Pollen sterility in M1 generation is the first sign of genetic effectiveness of the treatment. Pollen sterility increased with increase in concentration /dose of the mutagens. EMS treatment induced higher pollen sterility than the gamma radiation. The highest pollen sterility in present investigation was $10.34 \%$ with $40 \mathrm{mM}$ treatment. Lowest pollen sterility was recorded at $100 \mathrm{~Gy}$ and $10 \mathrm{mM}$ treatment of Gamma irradiation and EMS respectively. The result agreed to Barshile et.al (2006) in Chickpea employing SA, EMS and Gamma rays.

The percentage of survival a maturity decreased with increased concentration/dose of mutagens (Table-2).

The lowest percent survivals is found in 900Gy treatment of Gamma irradiation (60.89\%) and $40 \mathrm{mM}$ treatment of EMS (73.27). The Gamma irradiation was more effective than EMS. The decrease in survival of plant at maturity is due to rapid injection of chemical mutagen and their ability to produce chromosomal abstractions (Sharma et.al, 2005). Similar results were also obtained by Bashir et al, 2013 in Fenugreek. Kulkarni and Mogle, 2013 in Horse gram, Sangale et al, 2011 and Giri and Apparao, 2011 in Pigeonpea. Gamma irradiation had some effect on germination frequency of irradiated pigeon pea seeds. Germination frequency was decreased significantly after higher irradiation doses ranging from $300 \mathrm{Kr}$ to $900 \mathrm{Kr}$. Germination frequency was not much affected to seeds irradiated with $100 \mathrm{Kr}$ and control. Highest germination percentage was observed in control plants (Table 2) (96). Maximum decrease in percentage was observed in $900 \mathrm{Kr}$ irradiated plantlets (9). These records were in accordance with the result obtained by Amjad et al (2008) with chickpea. The results of Kiong et al (2008) shown that survival of plants to maturity depends on the damage nature and extent of chromosomal damage. Increasing frequency of chromosomal damage with increasing radiation dose may be responsible for less germination and reduction in plant growth and survival. Changes in the germination percentage were found to attribute to gamma rays treatments. The stimulating causes of gamma ray on germination may be certified to the activation of RNA or protein synthesis, which occurred during the early stage of germination after seed irradiated (Abdel-Hady et.al., 2008). Shoot length decreased in all doses of irradiation as compared to non irradiated. Maximum decrease was observed after 20kr dose (Amjad et.al 2008). In the present study, the variability as measured by mean values of the root/shoot lengths decreased with increase in the radiation dose. Choudhari (2002) reported that when radiation is sufficient to reduce the rooting percentages, then the root lengths do not exceed a few millimetres in length. Due to metabolic disorders in the seeds after gamma irradiation, the seeds are unable to germinate.

\section{CONCLUSION}

The present investigation was conducted to study the mutagenic effect of gamma rays, EMS in the local variety of pigeon pea. The main objective of the study was to induce the genetic variability in quantitative traits and to isolate the promising mutants associated with increase in yield potential of the crop. The significant findings are summarized as follows: The mutagenic effect studied on M1 parameters included seed germination, Seedling height, plant survival, pollen fertility, and various Quantitative traits. 
a) Seed germination, seedling growth, plant survival and pollen fertility decreased with an increase in mutagenic treatment.

c) Gamma rays proved to be most effective in causing maximum biological damage. The order of effectiveness was gamma rays > EMS.

d) Studies on various quantitative parameters showed the inhibitory effect of higher treatments and stimulatory effect of lower or intermediate treatments in M1 generation.

e) The mean values for various quantitative traits decreased at higher treatments, but stimulatory effects were noticed at some lower treatments.

f) A significant amount of variability was induced in the treated populations as compared to Control.

\section{REFERENCES:}

Abdel-Hady, M.S., E.M. Okasha, S.S.A. Soliman and Talaat. (2008). Effect of Gamma radiation and gibberlic acid on germination and alkaloid production in Atropa belladona. Aust. J. Basic Appl., 2(3):401-405.

Abu, J.O., K.Miller, K.G.Duodu and A. Minnar (2005). Gamma irradiation of cowpea (Vigna unguiculata L. Walp) flours and pastes. Food Chem., 95(1): 13-147.

Amjad hameed, Tariq mahmud Shaha, Babar Manzooor Atta, M. Ashnul Haq and Hina Sayed (2008). Gamma irradiation effects on seed germination and growth, protien content, peroxidase and protease activity, lipid peroxidation in desi and kabuli chickpea. Pak. J. Bot., 40(3): 1033-1041.

Anna Pick Kiong Ling, Jing Yi Chia, Sobri Hussein and Abdul Rahim Harun (2008) Physiological Responses of Citrus sinensis to Gamma Irradiation. World Applied Sciences Journal 5(1): 12
Arnon DI (1949). Copper enzymes in isolated chloroplasts polyphenol peroxidase in Beta vulgaris. Plant physiol 24: 1-15.

Aruna S. desai \& Srinath Rao (2014). Effect of Gamma radiation on germination and Physiological aspects of Pigeon Pea (Cajanus cajan (L.) Millsp. Seedlings. International Journal of Research in Applied, Natural and Social Sciences Vol. 2, Issue 6, Jun 2014, 47-52.

Ashri A and Herzog Z, 1972. Differential Physiological sensitivity of present verities to treatment with DES and EMS. Rad. Bot.12:173.

Barshile JD, SG Auti, SC Dalve and BJ Apparao, 2006. Mutagenic sensitivity studies in chickpea employing SA, EMS and gamma rays. Indian J. Pulses Res. 19(1):43-46.

Bashir, S Wani AA and Nawchoo IA, 2013. Studies on mutagenic effectiveness and efficiency in Fenugreek (Trigonella foenum-graecum L.). African J. Biote. 12(18): 2437-2440.

Bates, L.S. 1973. Rapid determination of free proline for water-stress studies. Plant Soil, 39:205- 207.

Borzouei, E., Kafi, M., Khazaei, H., Naseriyan. B and majdabadi (2010) Effects of Gamma radiation on germination and physiological aspects of wheat (Triticum aestivum L.) seedlings. Pak. J. Bot., 42(4): 2281-2290.

Charbaji, T. and I. Nobulsi, (1999). Effect of low doses of gamma irradiation on in vitro growth of Grapevine. Plant cell Tissue Organ Culture, 57(2): 129-132.

Chakravarty, B. and S. Sen, (2001). Enhancement of regeneration potential and variability by irradiation in cultured cells of Scilla indica. Biologia plantarum, 44(2): 189-193. 
Choudhary, K.S. (2002). A Simple and reliable method to detect gamma irradiated lentil (Lens culinaris Medic.) seeds by germination efficiency and seedling growth test. Radat. Phys. Chem., 64: 131136.

Corthals, G., S. Gygi, R. Abersold and S.D. Patterson, (2000). Identification of proteins by mass spectrometry. Proteome res., 2(1):286-290

Esfandiairi, E., M.R. Shakiba, S.A. Mahboob, H. Alyari and S. Shahabivand. (2008). The effect of water stress on antioxidant content, protective enzyme activities, proline content and lipid peroxidation in seedling wheat. Pak. J. Biol. Sci., 11(15): 1916-1922.

Gaul H, 1964. Mutations in plant breeding. Rad. Bot. 4:155-232.

Giri S. P. A.B. Tambe and B.J. Apparao (2010). Induction of a Novel, high yielding Mutant of Pigeon pea. Asian J. Exp. Biol. Sci. Spl. 152-155.

Giri SP and Apparoo BJ, 2011. Studies on Effectiveness and Efficiency of EMS in Pigeonpea Cajanus cajan (L.). Bioscience Discovery, 2(1):29-31.

Giri S. P. (2014). Studies of Mutagenic Sensitivity in Pigeonpea [Cajanus Cajan (L.) Mill sp.] Bioscience Discovery, 5(2):227-229.

Gunkel, J.E., Sparrow, A.H., and Sparrow, 1954. Ionizing radiations: Biochemical, Physiological and Morphological Aspects of their effects of plants. Encyclopedia of plant physiology, Springer-Verlag, Berlin (pp. 555-611).

Humera, A., 2006. Biochemical and Moecular Markers of Somaclonal Variants and Induced mutants of potato (Solanum tuberosum 1.) Thesis ((Ph.D). University of the Punjab Lahore, Pakistan.
Jain, S.M., Ahluwalia, B.S., Veilleux, R.E., Somaclonal variation and induced mutation in crop improvement. Plant Cell Tissue Organ Cult. 7(1), 23-28.

Jijiya B. J (1986). Mutation breeding in Phaseolus vulgaris 1. Ph.D thesis, Osmania University, Hyderabad.

Khan S and Wani MR, 2006. MMS and SA induced genetic variability for quantitative traits to Mungbean. Indian J. Pulses Res. 19(1):50-52.

Kim, J.H., M.H. Baek, B.Y. Chung, S.G. Wi and J.S. Kim, (2004). Alterations in the photosynthetic pigments and antioxidantt machinaries of red pepper (Capsicum annum L.) seedlings from- irradiated seeds. J. plant Biotechnol., 47(2):314321.

Kovacs, E. and A. Keresztes. (2002). Effect of gamma and UV-B/C radiation on plant cell. Micron 33: 199- 210.

Kulkarni GB and UP Mogle, 2013. Effects of mutagen on chlorophyll mutation in horse gram [macrotyloma uniflorum (Lam) Verdcourt]. Bioscience Discovery, $4(2): 214-219$.

Micke A, 1988. Genetic improvement of grain legumes using mutation. In: Proc. FAO/induced of IAEA, workshop on importance of grain legume production using indicated mutation 1-51.

Mundhe and Borse RD, 2012. Studies of Mutagenic Sensitivity in Soybean (Glycine max L.). J. Phytol. Res. 25 (2):239-240. Oliver H. Lowry, Nira J. Rosebrough (1951). Protein Measurement with the Folin Phenol reagent. The journal of biological chemistry 265-275. 
Oliver H. Lowry, Nira J. Rosebrough (1951). Protein Measurement with the Folin Phenol reagent. The journal of biological chemistry 265-275.

Predieri, S. (2001). Induced mutatuin and tissue culture in fruits. Plant Cell Tissue Organ Culture, 64(3):185-210.

Salunkhe DK, Kadam SS and Chavan JK, 1985. Post harvest Biotechnology of legumes. CRC press, Boca Raton Florida, pp.35160

Sangle SM, SE Mahamune, SN Kharat and VS Kothekar. 2011. Effect of Mutagenisis on Germination and Pollen Steritity In
Pigeonpea. Bio.sci. Discovery, 2(1):127130.

Sharma SK, Sood R and Pandey OP, 2005. Studies on Mutagen sensitivity, effectiveness and efficiency in Urd bean (Vigna mungo L. Hepper). Indian J. Genet. 65(1):20-22

Sudha Rani (1990). Mutation breeding in Phaseolus vulgaris 1. Ph.D thesis, Osmania University, Hyderabad

Zolla, L., A.M. Timperio, W. Walcher and C.G Huber, (2003). Proteomics of light harvesting protiens in different plant species. Plant Physiol., 131(2):198-214. 